\title{
Cytotoxic and haemagglutinating activities of motile Aeromonas species
}

\author{
K. N. MAJEED and I. C. MACRAE \\ Department of Microbiology, The University of Queensland, Brisbane, Queensland 4072, Australia
}

\begin{abstract}
Summary. Cytotoxic and haemagglutinating properties were determined in 114 Aeromonas strains isolated from various sites in slaughtered lambs and from processed lamb meat. Cytotoxic activity on Vero cells was observed in $48(42 \%)$ of the strains. It was more common in $A$. sobria and $A$. hydrophila isolates than with $A$. caviae isolates. Haemagglutination (HA) activity was found frequently in motile aeromonads irrespective of species; it was present in $50 \%$ of $A$. sobria strains, $51 \%$ of $A$. hydrophila strains and $48 \%$ of $A$. caviae strains. HA was inhibited by fucose, galactose and mannose at low concentration and, in most cases, two or three of these sugars were inhibitory. A significant association was found between certain HA-inhibition patterns and the production of cytotoxin by Aeromonas spp.
\end{abstract}

\section{Introduction}

The genus Aeromonas comprises a group of organisms widely distributed in the environment and associated with diseases in animals and man. The non-motile species are normally found in surface waters and in aquatic sediments when certain diseases of fish are prevalent. Motile aeromonads, on the other hand, have been reported to cause various infections in man, being most commonly implicated in diarrhoea, wound infections and septicaemia.

Unlike most other gram-negative organisms, Aeromonas spp. produce a wide range of extracellular toxins and enzymes. The multiplicity of extracellular products of motile Aeromonas spp. has led to difficulty in characterising these factors and to disagreement about their properties, as well as about their direct involvement in the enteropathogenicity of Aeromonas spp. This has resulted in a great deal of controversy and confusion. However, such extracellular biologically active factors as enterotoxins, cytotoxins, haemolysins and proteases have been reported to be produced by motile aeromonads and have been studied in relation to their pathogenicity. ${ }^{\mathbf{1 - 6}}$ Relatively little is known about the relationship between enterotoxin, haemolysin and cytotoxin produced by Aeromonas isolates. However, several reports ${ }^{2,3}$ suggest a parallel activity of these three factors in Aeromonas spp.

Cytotoxins generally give rise to cell damage or death and may produce dysentery-like illness. Gracey et al. ${ }^{7}$ reported that $20 \%$ of gastrointestinal infections due to Aeromonas spp. are of the dysenteric type. Furthermore, it has been reported repeatedly that the majority of clinical isolates of Aeromonas spp. produce cytotoxins..$^{3,5,8,9}$

Received 1 June 1993; revised version accepted 17 Aug. 1993.
Motile Aeromonas spp. have other properties that have been reported to be associated with virulence, such as adherence and invasiveness. The attachment of enteric pathogens to the intestinal mucosa is an essential step in the pathogenesis of gastrointestinal infections. It has been documented that adhesins are important factors for Escherichia coli ${ }^{\mathbf{1 0}}$ and strains of enterotoxigenic $E$. coli lacking these factors do not cause diarrhoea in animals ${ }^{11,12}$ or when fed to human volunteers. ${ }^{13}$ Carrello et al. ${ }^{14}$ studied the ability of Aeromonas spp. to adhere to HEp-2 cells. An association between diarrhoea and a high level of adhesion was observed in the majority of the faecal isolates and in none of the environmental isolates. The HA assay is the commonly used procedure to determine the ability of micro-organisms to adhere to eukaryotic cells. In this assay, erythrocytes from different animal species may be used. Further information on the nature and specificity of the receptors on the eukaryotic cell surface can be obtained by testing various sugars for their ability to inhibit the HA. It has been reported that enterotoxigenic diarrhoeal isolates of $A$. hydrophila showed HA activity, but no such activity was observed with non-toxigenic strains of $A$. caviae commonly isolated from nondiarrhoeal infections or the environment. ${ }^{15}$

The aim of this study was to determine the presence of cytotoxic and HA activities in Aeromonas spp. isolated from various sites in slaughtered lambs and from processed lamb meat.

\section{Materials and methods}

\section{Bacterial strains}

A total of 114 Aeromonas strains was included in this study. These were isolated from various sites in 
slaughtered lambs and from processed lamb meat and offal. Sampling procedures and isolation and characterisation of Aeromonas strains were described previously. ${ }^{16,17}$ The isolates included $A$. hydrophila (41 strains), A. sobria (24 strains), A. caviae (44 strains) and five atypical Aeromonas strains. Another six strains of Aeromonas spp. representative of different biotypes and known to have different toxin profiles were also included in this study as controls. These were obtained from Dr V. Burke of the Gastroenterology and Nutrition Research Unit, Princess Margaret Children's Medical Research Foundation, Perth, Western Australia. All strains were stored in maintenance medium at $4^{\circ} \mathrm{C} .{ }^{18}$

\section{Preparation of bacterial cultures}

Throughout the study, bacterial cultures were prepared by plating one loopful from the stock cultures of each Aeromonas strain on to Columbia agar plates containing sheep blood $5 \% \mathrm{v} / \mathrm{v}$ and incubated at $28^{\circ} \mathrm{C}$. Fresh cultures $(18-24 \mathrm{~h})$ were used for HA assays as well as for the preparation of cell-free supernates for cytotoxin assay.

\section{Preparation of cell-free supernates}

Several colonies from each blood agar plate were inoculated into $5 \mathrm{ml}$ of Tryptone Soy Broth (Oxoid) supplemented with Yeast Extract (Oxoid) $0.6 \% \mathrm{w} / \mathrm{v}$ in 25-ml Erlenmeyer flasks. These were incubated for $24 \mathrm{~h}$ at $37^{\circ} \mathrm{C}$ with agitation at $300 \mathrm{rpm}$ in an environmental incubator shaker (New Brunswick Scientific, Edison, NJ, USA). Cell-free preparations were made by centrifuging the cultures at $10000 \mathrm{~g}$ for $30 \mathrm{~min}$ at $4^{\circ} \mathrm{C}$, followed by filtration of the supernate through a membrane filter (pore size $0.45 \mu \mathrm{m}$, Minisart NML, Sartorius). Cell-free supernates were stored at $-20^{\circ} \mathrm{C}$ and tested for cytotoxic activity within 6 weeks. ${ }^{19}$

\section{Cytotoxin assay}

Cytotoxic activity was detected in Vero cells by the method of Sack and Sack. ${ }^{20}$ Medium 199 was obtained from Grand Island Biological Co. (Gibco), while all other tissue culture media and sera were obtained from the Commonwealth Serum Laboratories (CSL), Melbourne, Australia. Vero cells were maintained in M199 supplemented with fetal calf serum $2 \% \mathrm{v} / \mathrm{v}$. The tissue culture was subcultured into $60-\mathrm{mm}$ petri dishes and was available for assay when a monolayer was formed, usually within $48 \mathrm{~h} ; 400 \mu \mathrm{l}$ of each cell-free supernate was added to a tissue culture growing in a $60-\mathrm{mm}$ petri dish with $3.6 \mathrm{ml}$ of medium. All incubations were in a humidified incubator in air with $\mathrm{CO}_{2}$ $5 \%$ at $37^{\circ} \mathrm{C}$. The cells were observed after different periods of incubation with a phase-contrast inverted microscope for the presence of disruptive changes and detachment of cells. Cell-free supernates from known positive and negative strains were included as controls.

\section{$H A$ and $H A$-inhibition (HAI) assays}

These were done by the method of Atkinson and Trust. ${ }^{21}$ Human group $\mathrm{O}$ blood was obtained from Red Cross Packs (Red Cross Blood Bank, Brisbane, Australia) $<7$ days after collection. Immediately before use, blood cells were washed three times in single strength Dulbecco's phosphate-buffered saline (DPBS; CSL) and prepared as a suspension of $3 \% \mathrm{v} / \mathrm{v}$ in DPBS.

Bacterial suspensions were made by adding two loopfuls from fresh (18-24 h) cultures on sheep blood agar to $0.5 \mathrm{ml}$ of phosphate-buffered saline (PBS), to provide a concentration of $c .10^{11}$ organisms $/ \mathrm{ml}$.

Stock solutions of fucose, galactose or mannose (Sigma) $10 \% \mathrm{w} / \mathrm{v}$ in sterile distilled water were stored at $4^{\circ} \mathrm{C}$ for not more than 4 weeks. On the day of the test, working solutions of $1 \% \mathrm{w} / \mathrm{v}$ were prepared by dilution with PBS.

HA tests were done at room temperature by mixing $20 \mu \mathrm{l}$ of each bacterial suspension with the same volume of blood suspension on a white porcelain tile, which was then placed on a mechanical rotary table (Card test rotator, Model 74; Hynson, Westcott and Dunning Inc., Baltimore, USA). A control consisting of equal volumes of blood suspension and PBS was included on each tile. Aeromonas strains were considered to be HA-negative if HA had not occurred within $5 \mathrm{~min}$. HA was recorded as $2+$ (strong) if the reaction was immediate and complete, or as $1+$ if the reaction was incomplete or not instantaneous but occurred within $5 \mathrm{~min}$.

HAI tests were done at room temperature by mixing $20 \mu \mathrm{l}$ of blood suspension, $20 \mu \mathrm{l}$ of a solution of the test sugar $1 \% \mathrm{w} / \mathrm{v}$ in PBS plus $20 \mu 1$ of each bacterial suspension. The suspensions were mixed as described earlier. Reactions were compared with positive controls consisting of equal volumes of bacterial suspension (HA-positive) and blood suspension, and a negative control with two volumes of PBS and one volume of blood suspension. Inhibition was recorded if previously positive $\mathrm{HA}$ became negative or if strong HA $(2+)$ became weak $(1+)$ in the presence of sugar solutions.

\section{Results}

The results of tests for the cytotoxic and HA properties of Aeromonas strains are shown in table I. Of the 114 Aeromonas strains tested, $48 \quad(42 \%)$ produced cytotoxic effects on Vero cells. Cytotoxic activities were observed with $26(63 \%)$ of the $A$. hydrophila strains, $19(79 \%)$ of the $A$. sobria strains and with only three $(7 \%)$ of the $A$. caviae strains. None of the five atypical Aeromonas strains was capable of producing cytotoxic effects on Vero cells. Vacuolation in the cytoplasm of the Vero cells was the first sign of cytotoxicity. After further incubation, the cells were pycnotic and often floating in the medium 
Table I. Cytotoxic and HA activities of Aeromonas spp. and HAI by various sugars

\begin{tabular}{lcccccc}
\hline & & \multicolumn{5}{c}{$\begin{array}{c}\text { Number of strains (\%) } \\
\text { giving a positive result for }\end{array}$} \\
\cline { 3 - 6 } $\begin{array}{l}\text { Aeromonas } \\
\text { sp. }\end{array}$ & $\begin{array}{c}\text { Number } \\
\text { of } \\
\text { strains }\end{array}$ & \multicolumn{5}{c}{ HAI by } \\
\cline { 3 - 7 } & & cytotoxin & HA & fucose & galactose & mannose \\
\hline $\begin{array}{l}\text { A. hydrophila } \\
\text { A. sobria }\end{array}$ & 41 & $26(63)$ & $21(51)$ & $18(86)$ & $15(71)$ & $19(90)$ \\
A. caviae & 24 & $19(79)$ & $12(50)$ & $6(50)$ & $8(67)$ & $9(75)$ \\
Atypical & 44 & $3(7)$ & $21(48)$ & $21(100)$ & $15(71)$ & $21(100)$ \\
Total & 5 & 0 & $2(40)$ & $2(100)$ & $1(50)$ & $2(100)$ \\
& 114 & $48(42)$ & $56(49)$ & $47(84)$ & $39(70)$ & $51(91)$ \\
\hline
\end{tabular}

(figure). Early cytotoxic effects (after incubation for $4 \mathrm{~h}$ ) were commonly produced by $A$. sobria isolates. Of the 19 cytotoxic $A$. sobria strains, $13(68 \%)$ were able to produce cytotoxic effects in Vero cells after incubation for $4 \mathrm{~h}$. With $A$. hydrophila isolates, only 10 $(38 \%)$ strains were able to produce early cytotoxic events. All three cytotoxic $A$. caviae strains produced disruptive changes in Vero cells after incubation for $8-12 \mathrm{~h}$.

The sources of the Aeromonas strains examined and the number of cytotoxin-producing strains are shown in table II. The majority of Aeromonas strains obtained from kidney and liver samples produced cytotoxin. Of the 15 kidney strains, $14(93 \%)$ produced cytotoxin. Similarly, of the 15 liver strains, $12(80 \%)$ produced cytotoxin. However, strains isolated from minced meat samples generally failed to produce cytotoxin. Only two $(10 \%)$ of the 20 strains tested were able to produce this factor. There was no significant correlation between cytotoxic activity and source of the isolates in lamb cuts samples, carcass swabs and lamb faeces. Cytotoxic activity was noted in $22 \%, 37 \%$ and $36 \%$ of Aeromonas isolates from these samples, respectively.

Screening of the 114 strains of different Aeromonas spp. showed that HA is a common property of these micro-organisms (table I), as 56 strains were able to agglutinate human group $\mathrm{O}$ red blood cells. However, there were no significant differences in the HA ability of the three main Aeromonas spp. Agglutination of human red blood cells was noted with $21(51 \%) A$. hydrophila strains, $12(50 \%) A$. sobria strains and 21 (48\%) A. caviae strains. Strong $(2+)$ HA was common among $A$. sobria and $A$. caviae strains and, of those

Table II. Cytotoxin production and source of isolation of Aeromonas strains

\begin{tabular}{lcr}
\hline $\begin{array}{l}\text { Source of } \\
\text { strains }\end{array}$ & $\begin{array}{c}\text { Number of } \\
\text { strains tested }\end{array}$ & $\begin{array}{c}\text { Number of strains (\%) } \\
\text { producing cytotoxin }\end{array}$ \\
\hline Lamb cuts & 23 & $5(22)$ \\
Minced meat & 20 & $2(10)$ \\
Kidney & 15 & $14(93)$ \\
Liver & 15 & $12(80)$ \\
Carcass swabs & 27 & $10(37)$ \\
Lamb faeces & 14 & $5(36)$ \\
Total & 114 & $48(42)$ \\
\hline
\end{tabular}
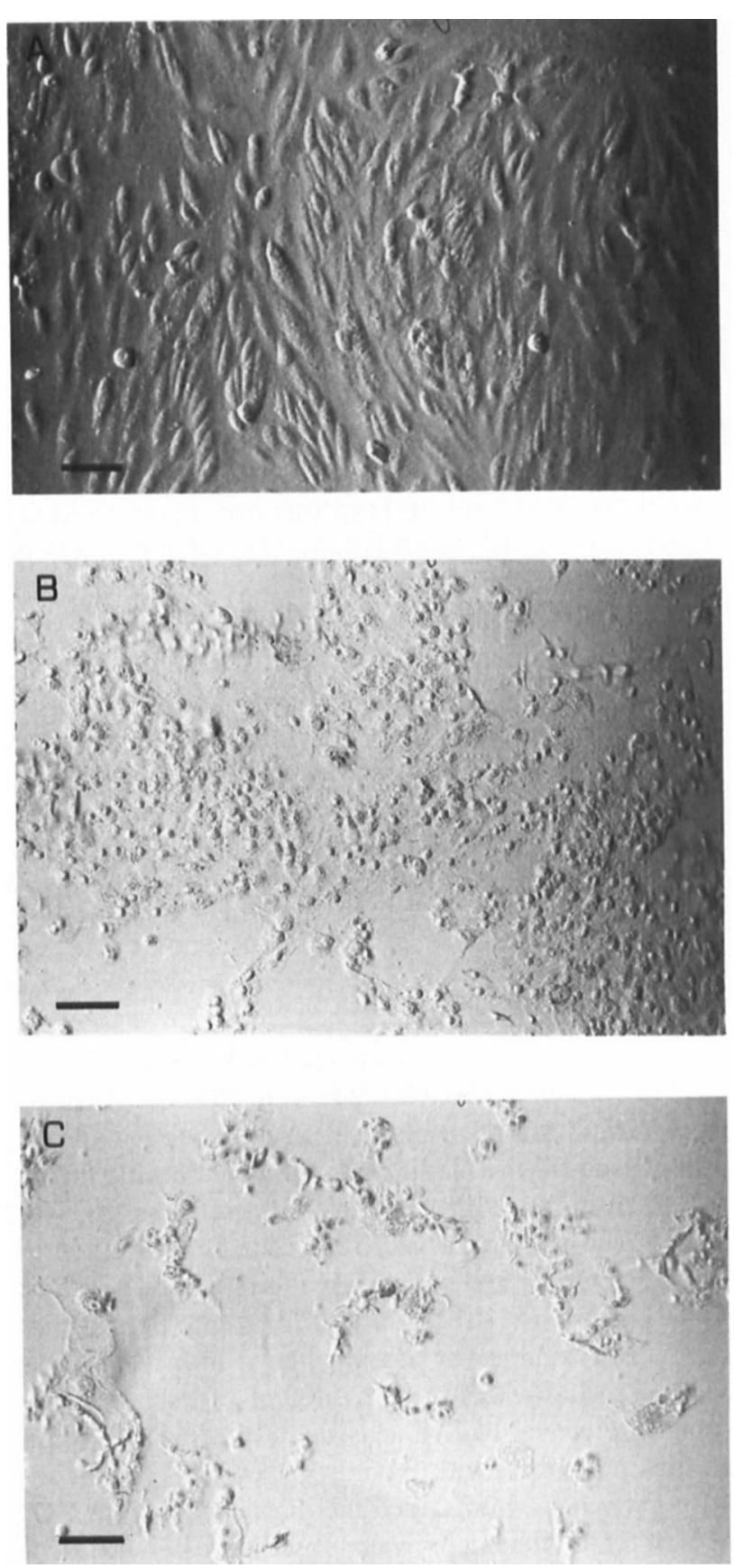

Figure. Vero cell assay for Aeromonas cytotoxin: A, negative control ; B, cytotoxin response elicited by $A$. hydrophila strain after incubation for $4 \mathrm{~h}$ at $37^{\circ} \mathrm{C} ; \mathbf{C}$, after $8 \mathrm{~h}$. (Bar $=10 \mu \mathrm{m}$.) 
Table III. Patterns of HAI by fucose, galactose and mannose in relation to cytotoxin production by Aeromonas species

\begin{tabular}{|c|c|c|c|c|}
\hline \multirow{2}{*}{$\begin{array}{l}\text { Pattern } \\
\text { of HAI }\end{array}$} & \multicolumn{4}{|c|}{ Number of isolates showing HAI pattern $\dagger$} \\
\hline & A. hydrophila & A. sobria & A. caviae & Atypical \\
\hline $\mathrm{F}+\mathrm{G}-\mathrm{M}-$ & $1(1)$ & $2(1)$ & 0 & 0 \\
\hline $\mathrm{F}-\mathrm{G}+\mathrm{M}-$ & $1(1)$ & $1(0)$ & 0 & 0 \\
\hline $\mathrm{F}-\mathrm{G}-\mathrm{M}+$ & $1(1)$ & $2(2)$ & 0 & 0 \\
\hline $\mathrm{F}+\mathrm{G}-\mathrm{M}+$ & $4(4)$ & 0 & $6(0)$ & $1(0)$ \\
\hline $\mathrm{F}-\mathrm{G}+\mathrm{M}+$ & $1(1)$ & $3(3)$ & 0 & 0 \\
\hline $\mathrm{F}+\mathrm{G}+\mathrm{M}+$ & $13(9)$ & $4(4)$ & $15(0)$ & $1(0)$ \\
\hline
\end{tabular}

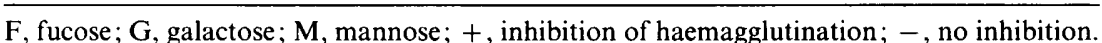
$\dagger$ Numbers in parentheses indicate strains that produced cytotoxin.

that were HA-positive, $2+$ activity was recorded in $82 \%$ and $76 \%$ of the strains of these species, respectively. Only $52 \%$ of the HA-positive $A$. hydrophila strains produced $2+$ HA with human erythrocytes.

When Aeromonas strains were grouped in relation to the effect of fucose, galactose and mannose on HA (table III), the commonest grouping among the strains ( 33 of 56) was demonstrated when the HA activity was inhibited by the three sugars $(F+G+M+)$. It was less common for only one of the three sugars tested to inhibit HA ( 8 of 56), and in other cases (15 of 56) HA was inhibited by two sugars.

The relationship between cytotoxin production and certain HAI patterns is also shown in table III. All the strains in groups $F-G-M+$ and $F-G+M+$ produced cytotoxic effects on Vero cells. However, no significant correlation was observed with the other HAI patterns.

\section{Discussion}

In this study, production of cytotoxin was found frequently among Aeromonas strains isolated from different lamb samples. A similar finding was obtained by other investigators who examined aeromonad food isolates for various virulence-associated factors, particularly cytotoxin and haemolysin. ${ }^{22-27}$ However, the prevalence of virulent strains varied from one study to another, and depended upon the type of test employed and the number and species of Aeromonas isolates tested. In this study, cytotoxic activity was observed in $63 \%$ of $A$. hydrophila strains from different lamb samples whereas Callister and Agger, ${ }^{23}$ Okrend et al. ${ }^{24}$ and Palumbo et al. ${ }^{27}$ reported cytotoxic activity in 100 , 92.8 and $98 \%$ of their $A$. hydrophila isolates from vegetables, raw meat and poultry and retail fresh foods of animal origin, respectively. In contrast, Fricker and Tompsett ${ }^{26}$ reported a lower prevalence $(45 \%)$ of cytotoxic $A$. hydrophila strains isolated from various foods.

Many authors have noted the production of exotoxins (enterotoxin, haemolysin and cytotoxin) by Aeromonas spp. However, the tendency for this to be confined to $A$. hydrophila and $A$. sobria has been observed previously. ${ }^{9,19,26,28-30}$ This was also confirmed in the present study where the majority of $A$. hydrophila and $A$. sobria strains but only a few strains of $A$. caviae were able to produce cytotoxin. These findings support previous observations that Aeromonas gastroenteritis is a spectrum of species-related diseases, being associated mostly with $A$. hydrophila and $A$. sobria. In addition, this study has also shown that $A$. sobria is more likely than the other two Aeromonas spp. to be virulent. This conclusion is supported by the following results: (a) the prevalence of strains that were able to produce cytotoxin was higher in this species than in the other two species, and (b) the incidence of strains that produced early cytotoxic effects in Vero cells was highest in the A. sobria group. A similar conclusion had been reached by other investigators ${ }^{28,31,32}$ but the criteria used for evaluation of virulence were different from those used in the present study.

Relatively little is known about the correlation between exotoxin production and the type of sample in Aeromonas strains of food origin. The only related study was that of Fricker and Tompsett ${ }^{26}$ who examined various foods, including poultry, pork, beef, offal, fish, cooked meats and prepared salads. They found no significant correlation between the type of food yielding the strains and the ability of the strains to produce cytotoxin. However, in the present study, a high incidence of cytotoxin-positive strains was detected among the group of strains isolated from kidney and liver samples.

In common with other observations ${ }^{15,21,32-35}$ the results of this study demonstrate that the ability to agglutinate human erythrocytes is not an uncommon property among motile aeromonads, as $c .50 \%$ of the Aeromonas strains had this ability. The results also showed a lack of correlation between HA ability and certain Aeromonas spp. and this supports the conclusion of Singh and Sanyal. ${ }^{35}$ The haemagglutinins, however, can be inhibited by sugars in low concentrations. The patterns of HA and HAI reflect important colonisation factors of $E$. coli $^{36}$ but their relation to virulence in Aeromonas strains is not fully defined.

Data from this work suggest that HAI patterns cannot be interpreted in relation to the effects of a 
single sugar, and such a phenomenon has also been observed by Burke et al..$^{15}$ Accordingly, this study describes the HAI patterns in relation to the effects of three sugars (fucose, galactose and mannose) and the possible association of certain inhibition patterns with cytotoxin production among Aeromonas strains. Results show a strong association $(100 \%)$ between cytotoxin production by Aeromonas strains and HAI in groups $\mathrm{F}-\mathrm{G}-\mathrm{M}+$ and $\mathrm{F}-\mathrm{G}+\mathrm{M}+$. Burke et al. ${ }^{15}$ reported that $75 \%$ of Aeromonas strains in these groups were enterotoxigenic, whereas Singh and Sanyal ${ }^{35}$ found that most of their strains in group $\mathrm{F}-\mathrm{G}+\mathrm{M}+$ were non-toxigenic. In the present study, only $39 \%$ of Aeromonas strains in group F $+\mathrm{G}+\mathrm{M}+$ were cytotoxin producers. In contrast, Burke et al.,$^{15}$ as well as Singh and Sanyal ${ }^{35}$ reported a higher degree of association between enterotoxin production by Aeromonas strains and inhibition of $\mathrm{HA}$ in the same group $(\mathrm{F}+\mathrm{G}+\mathrm{M}+)$. The interpretation of other inhibition patterns is not conclusive. Because of the limited numbers of Aeromonas strains in each group with a particular HAI pattern as demonstrated in this study, further data are still required to confirm the usefulness of these tests in the definition of virulent Aeromonas strains.

Cytotoxic and HA activities, as detected in Aeromonas strains, have been implicated in bacterial pathogenicity. The presence of significant levels of Aeromonas strains with these activities in samples from retail lamb meat and offal and on lamb carcasses indicates that food of animal origin may play a significant role in the epidemiology of Aeromonasassociated gastroenteritis.

The authors would like to acknowledge the assistance provided by Ms Dawn Grassick, Mrs Ibtisam Jabbar and Dr Allan Cody during various stages of the study.

\section{References}

1. Annapurna E, Sanyal SC. Enterotoxicity of Aeromonas hydrophila. J Med Microbiol 1977; 10: 317-323.

2. Donta S, Haddow AD. Cytotoxic activity of Aeromonas hydrophila. Infect Immun 1978; 21: 989-993.

3. Cumberbatch N, Gurwith MJ, Langston C, Sack RB, Brunton JL. Cytotoxic enterotoxin produced by Aeromonas hydrophila: relationship of toxigenic isolates to diarrheal disease. Infect Immun 1979; 23: 829-837.

4. Allan BJ, Stevenson RM. Extracellular virulence factors of Aeromonas hydrophila in fish infections. Can $J$ Microbiol 1981; 27: 1114-1122.

5. Johnson WM, Lior H. Cytotoxicity and suckling mouse reactivity of Aeromonas hydrophila isolated from human sources. Can J Microbiol 1981; 27: 1019-1027.

6. Stelma GN, Johnson $\mathrm{CH}$, Spaulding P. Evidence for direct involvement of $\beta$-haemolysin in Aeromonas hydrophila enteropathogenicity. Curr Microbiol 1986; 14: 71-77.

7. Gracey M, Burke V, Robinson J. Aeromonas-associated gastroenteritis. Lancet 1982; 2: 1304-1306.

8. Janda JM, Bottone EJ, Skinner CV, Calcaterra D. Phenotypic markers associated with gastrointestinal Aeromonas hydrophila isolates from symptomatic children. J Clin Microbiol $1983 ; 17: 588-591$

9. Gosling PJ. Biochemical characteristics, enterotoxigenicity and susceptibility to antimicrobial agents of clinical isolates of Aeromonas species encountered in the western region of Saudi Arabia. J Med Microbiol 1986; 22: 51-55.

10. Klemm P. Fimbrial adhesins of Escherichia coli. Rev Infect Dis 1985; $7: 321-340$

11. Bertschinger HU, Moon HW, Whipp SC. Association of Escherichia coli with the small intestinal epithelium. 1. Comparison of enteropathogenic and nonenteropathogenic porcine strains in pigs. Infect Immun 1972; 5: 595-605.

12. Burrows MR, Sellwood R, Gibbons RA. Haemagglutinating and adhesive properties associated with the K99 antigen of bovine strains of Escherichia coli. J Gen Microbiol 1976; 96: 269-275

13. Satterwhite TK, Evans DG, Dupont HL, Evans DJ. Role of Escherichia coli colonisation factor antigen in acute diarrhoea. Lancet 1978; 2: 181-184.

14. Carrello A, Silburn KA, Budden JR, Chang BJ. Adhesion of clinical and environmental Aeromonas isolates to HEp-2 cells. J Med Microbiol 1988; 26: 19-27.

15. Burke V, Cooper M, Robinson J et al. Haemagglutination patterns of Aeromonas spp. in relation to biotype and source. J Clin Microbiol 1984; 19: 3943.
16. Majeed KN, Egan AF, MacRae IC. Enterotoxigenic aeromonads in retail lamb meat and offal. $J$ Appl Bacteriol 1989; 67: 165-170.

17. Majeed KN, Egan AF, MacRae IC. Incidence of aeromonads in samples from an abattoir processing lambs. $J$ Appl Bacteriol 1989; 67: 597-604.

18. Burke V, Robinson J, Atkinson HM, Gracey M. Biochemical characteristics of enterotoxigenic Aeromonas spp. J Clin Microbiol 1982; 15: 48-52.

19. Figura N, Marri L, Verdiani S, Ceccherini C, Barberi A. Prevalence, species differentiation and toxigenicity of Aeromonas strains in cases of childhood gastroenteritis and in controls. J Clin Microbiol 1986; 23 : 595-599.

20. Sack DA, Sack RB. Test for enterotoxigenic Escherichia coli using Y-1 adrenal cells in miniculture. Infect Immun 1975; 11: $334-336$

21. Atkinson HM, Trust TJ. Haemagglutination properties and adherence ability of Aeromonas hydrophila. Infect Immun 1980; 27: 938-946.

22. Abeyta C, Kaysner CA, Wekell MM, Sullivan JJ, Stelma GN. Recovery of Aeromonas hydrophila from oysters implicated in an outbreak of foodborne illness. $J$ Food Prot $1986 ; 49$ : 643-646.

23. Callister SM, Agger WA. Enumeration and characterization of Aeromonas hydrophila and Aeromonas caviae isolated from grocery store produce. Appl Environ Microbiol 1987; 53: 249-253.

24. Okrend AJ, Rose BE, Bennett B. Incidence of toxigenicity of Aeromonas species in retail poultry, beef and pork. $J$ Food Prot 1987; 50: 509-513.

25. Ternstrom A, Molin G. Incidence of potential pathogens on raw pork, beef and chicken in Sweden with special reference to Erysipelothrix rhusiopathiae. J Food Prot 1987; 50: 141-146.

26. Fricker CR, Tompsett S. Aeromonas spp. in foods: a significant cause of food poisoning? Int J Food Microbiol 1989; 9: $17-23$.

27. Palumbo SA, Bencivengo MM, Del Corral F, Williams AC, Buchanan RL. Characterization of the Aeromonas hydrophila group isolated from retail foods of animal origin. $J$ Clin Microbiol 1989; 27: 854-859.

28. Barer MR, Millership SE, Tabaqchali S. Relationship of toxin production to species in the genus Aeromonas. $J \mathrm{Med}$ Microbiol 1986; 22 : 303-309.

29. Kirov SM, Rees B, Wellock RC, Goldsmid JM, Van Galen AD. Virulence characteristics of Aeromonas spp. in relation to source and biotype. J Clin Microbiol 1986; 24: 827-834.

30. Megraud F. Incidence and virulence of Aeromonas species in faeces of children with diarrhea. Eur J Clin Microbiol 1986; 5: $311-316$. 
31. Daily OP, Joseph SW, Coolbaugh JC et al. Association of Aeromonas sobria with human infection. J Clin Microbiol 1981; 13: 769-777.

32. Watson IM, Robinson JO, Burke V, Gracey M. Invasiveness of Aeromonas spp. in relation to biotype, virulence factors, and clinical features. J Clin Microbiol 1985; 22: 48-51.

33. Adams D, Atkinson HM, Woods WH. Aeromonas hydrophila typing scheme based on patterns of agglutination with erythrocytes and yeast cells. $J$ Clin Microbiol 1983; 17 : $422-427$.
34. Burke V, Cooper M, Robinson J. Haemagglutination patterns of Aeromonas spp. related to species and source of strains. Aust J Exp Biol Med Sci 1986; 64: 563-570.

35. Singh DV, Sanyal SC. Haemagglutinating activity, serum sensitivity and enterotoxigenicity of Aeromonas spp. J Med Microbiol 1993; 38: 49-53.

36. Evans DG, Evans DJ, Tjoa W. Haemagglutination of human group A erythrocytes by enterotoxigenic Escherichia coli isolated from adults with diarrhea: correlation with colonization factor. Infect Immun 1977; 18: 330-337. 